\title{
The Effectiveness Of Death Execution On Narcotics Crime As Law Enforcement
}

\author{
Tithos Briyan Pamungkas Sumanang*) and Amin Purnawan**) \\ *)Universitas Islam Sultan Agung (UNISSULA) Semarang, E-mail: \\ tithosmh36@std.unissula.ac.id \\ **) Faculty of Law Universitas Islam Sultan Agung
}

\begin{abstract}
This study aims to review the Narcotics Law that applies in Indonesia, especially Act No. 35 of 2009 concerning Narcotics. In addition, this research is also expected to find out the obstacles and solutions in law enforcement efforts against narcotics criminals. The research approach method that will be used in the research is the juridical-sociological method. From the results of this study, it is concluded that theoretically the applicable narcotics law has been very effective in investigating narcotics criminals, and in practice the law is also very helpful in completing investigations against narcotics criminals in Indonesia and the execution of the death penalty is one of the hard law enforcement efforts to emphasize that narcotics abuse is a very dangerous thing. However, the problem of narcotics abuse is not only a national problem, it has become an international problem that cannot be solved only with existing regulations, professionals from law enforcement officials are also very much needed in cracking down on narcotics abuse, and the role of public awareness is also important, in order to stay away from narcotics abuse.

Keywords: Execution; Death Penalty; Law Enforcement; Narcotics.
\end{abstract}

\section{Introduction}

Narcotics are substances or drugs that are natural, synthetic, or semisynthetic which cause a decrease in consciousness, hallucinations, and excitability. According to Act No. 35 of 2009 concerning narcotics in article 1 paragraph 1 states that narcotics are substances or drugs derived from plants or non-plants, both synthetic and semi-synthetic, which can cause a decrease or change in consciousness, loss of taste, reduce to relieve pain, and can cause dependence, which are divided into groups as attached in this law, ${ }^{1}$ namely group I, group II, and group III. From the classification of these types of narcotics it has a dangerous effect for its users.

Drug abuse is one of the crimes that still cannot be solved, both in Indonesia and in the world. Although narcotics are useful for medical and scientific purposes, if they are not used properly, they will have negative effects that can lead to death. Drug abuse also causes a negative impact on society, which can increase crime rates. In the development of the law that regulates narcotics, it is a cycle that is inseparable from the dynamics of the social development of society in Indonesia. In addition to issuing laws governing narcotics, the Indonesian government has also established a special agency to deal with narcotics issues.

\footnotetext{
${ }^{1}$ Exemplification of the Act No. 35 of 2009 concerning Narcotics, Article 1 Paragraph 1.
} 
Although the Indonesian government has issued a law that specifically regulates narcotics, and formed a special agency to deal with narcotics problems, abuse in the illicit traffic of narcotics has increased. Until now, from statistical data released by the National Narcotics Agency (BNN) of the Republic of Indonesia, it shows that the trend of illicit trafficking and narcotics abuse continues to increase every year. ${ }^{2}$ The number of narcotics crime cases that occurred during 2010 to 2014 , can be seen from the table as follows: ${ }^{3}$

Table 1.1. Number of Narcotics Crimes in 2010-2014

\begin{tabular}{lllllll}
\hline \multirow{2}{*}{ NO } & \multirow{2}{*}{ CASE } & \multicolumn{3}{l}{ YEAR } & & \\
\cline { 2 - 6 } & & 2010 & 2011 & 2012 & 2013 & 2014 \\
\hline 1 & Narcotics & 17,898 & 19,129 & 19,081 & 21,269 & 23.134 \\
\hline TREND & - & $6.87 \%$ & $-0.25 \%$ & $11.47 \%$ & $8.77 \%$ \\
\hline
\end{tabular}

Along with the increase in the number of narcotics crime cases, there was also an increase in the number of perpetrators involved in illicit trafficking and narcotics abuse in 2010 to 2014, which can be seen from the following table: ${ }^{4}$

Table 1.2. Number of Perpetrators of Narcotics Abuse in 2010-2014

\begin{tabular}{lllllll}
\hline & & \multicolumn{2}{l}{ YEAR } & & & \\
\cline { 2 - 7 } NO & PERPETRATOR & $\mathbf{2 0 1 0}$ & $\mathbf{2 0 1 1}$ & $\mathbf{2 0 1 2}$ & $\mathbf{2 0 1 3}$ & $\mathbf{2 0 1 4}$ \\
\hline 1 & Narcotics & 23.975 & 25,297 & 25,309 & 28,788 & 31,084 \\
\hline TREND & - & $5.51 \%$ & $0.05 \%$ & $13.75 \%$ & $7.98 \%$ \\
\hline
\end{tabular}

To prevent and eradicate abuse and illicit trafficking of narcotics which is very detrimental and endangers the lives of the community, nation and state, synergy between the community and the authorities against narcotics criminals is needed, such as the role of the National Narcotics Agency, the Police, and the Attorney General's Office. In Bandung, the Class IIA female detention center in collaboration with the National Narcotics Agency, the National Police, and the TNI conducted a joint search operation in the inmates' residences. As a result, no narcotics or cellphones were found in the prisoners' hands. Officers only confiscate items that are considered dangerous. Among them are nail clippers, cable wire, tweezers, iron nails, small cutters, glass perfume, and matches. The search was led by the Head of Class IIA Bandung Women's Detention Center, Moneka Mayamurti, Bc, IP, SH. and Head of the West Java Ministry of Law and Human Rights' Detention Service Division, Saifur Rachman. Head of Class IIA Bandung Women's Detention Center, Moneka Mayamurti, said the search was carried out on 99 (ninety nine) inmates. This activity is an effort to prevent the potential circulation of narcotics in the prison environment. ${ }^{5}$

\footnotetext{
2Rahman Amin, 2020, Perlindungan Hukum Justice Collaborator Dalam Sistem Peradilan Pidana di Indonesia: Studi Perkara Tindak Pidana Narkotika, Deepublish, Yogyakarta p. 5-6.

3 Ibid.

4 Ibid.

5 Sandy Ferdiana, 7 April 2021, "Kemenkumham dan Polri Razia Narkotika di Rutan Perempuan", https://www.republika.co.id/berita/qr6kg8371/kemenkumham-dan-polri-razia-narkotika-di-rutanperempuan, accessed on 27 June 2021.
} 
In other cases such as the case of the handsome actor Rio Reifan who was re-arrested for narcotics abuse, this is the fourth time that Rio Reifan has been arrested by the police, and the last arrest was on August 13, 2019.6 Another case regarding drug abuse from Makassar which was published on the website page www.makasarmetro.com, published on April 24, 2021, with the title "Police Arrest Assistant I Makassar City Government, Alleged Drug Abuse", wrote Makassar Police Arrest Assistant I City Government, M Sabri , on suspicion of drug abuse. Apart from Sabri, three other officials were arrested. They are the head of the Makassar City Government. And these cases are $0.1 \%$ of narcotics abuse cases in Indonesia. ${ }^{7}$

The number of abuse cases that occur in Indonesia is a task that must be completed by all communities, not only from law enforcement agencies and agencies, but the level of public awareness of the dangers of narcotics is also very important in efforts to enforce narcotics crime law. Prevention counseling for all circles is very necessary, especially counseling for underage children and adolescents who are still looking for their identity, who lack knowledge and supervision of the dangers of narcotics abuse. Moreover, all people have the right to get knowledge about the character of narcotics, from the dangerous effects of their abuse to criminal sanctions, because many people do not know what narcotics are. Most of the people are aware of the dangers, but do not know about the character of narcotics that can harm themselves. This will trigger a greater negative impact on the nation and the younger generation in this beloved country.

The young generation is the hope of the Indonesian people, because in the soul of the young generation each will bring progress to the nation and the country, therefore as a society in a country that upholds education and morality, we are obliged to participate in guarding so that there are no cases of drug abuse that occur every year is always found in various places in Indonesia and even in the world. And the strengthening of sanctions for drug abuse is very much needed. The existence of criminal and criminal penalties contained in the law on narcotics abuse is very helpful in solving narcotics problems, although in practice there are still obstacles that have not been resolved.

Based on the description above, the objectives of the research compiled in this legal journal are: To review Act No. 35 of 2009 concerning Narcotics in law enforcement efforts; To analyze how effective the narcotics law is in resolving narcotics abuse cases in Indonesia; To analyze the obstacles and solutions of criminal sanctions against narcotics criminals, especially the execution of the death penalty.

\section{Research Methods}

\footnotetext{
6 Vicentius Mario, Andika Aditia, 20 April 2021, "Rio Reifan Kembali Ditangkap Terkait Penyalahgunaan Nakoba", https://www.kompas.com/hype/read/2021/04/20/092808066/rioreifan-kembali-ditangkap-terkait-penyalahgunaan-narkoba, Retrieved 27 June 2021.

7 Makassarmetro, 24 April 2021, "Polisi Tangkap Asisten I Pemkot Makassar, Dugaan Penyalahgunaan Narkoba", https://makassarmetro.com/2021/04/24/polisi-tangkap-asisten-ipemkot-makassar-dugaan-penyalahgunaan-narkoba, accessed on 27 June 2021.
} 
The approach method used in this research is juridical-sociological. Specifications This research is descriptive analytical. Sources of data used in the preparation of writing this research are: primary data, and secondary data. Secondary Data includes Primary Legal Materials, Secondary Legal Materials and Tertiary Legal Materials. The data collection technique used in this study was conducted through interviews (field research) to several sources related to this research, namely several narcotics crime investigators. And to obtain secondary data, it was carried out using library research, namely the research was conducted using literatures and laws and regulations. The data to be obtained will be analyzed qualitatively, namely the data obtained describe according to the actual situation,

\section{Results and Discussion}

\subsection{Law Enforcement of Narcotics Crime A Study of Act No. 35 of 2009 concerning Narcotics}

Narcotics in pharmacological-medical terms, narcotics are drugs that can eliminate (especially) pain originating from the visceral area, and which can cause a stupor effect (stupid, still conscious but must be bluffed) and addiction. The definition according to the narcotics Act No. 9 of 1976, narcotics are drugs or medicinal materials belonging to the above definition, and drugs or medicinal materials derived from coca plants and marijuana plants. ${ }^{8}$ Thus, narcotics or narcotics are narcotics and psychotropics as well as dangerous substances that cannot be used freely, except for the interests of health, science, and research related to the terms and conditions that apply based on the laws and regulations.

The use of pharmaceutical preparations in the form of narcotics and psychotropics can only be carried out based on a doctor's or dentist's prescription and misuse is prohibited. ${ }^{9}$ The prohibition of consuming narcotics began with the issuance of the Single Convention on Narcotics Drugs in 1961. America pioneered the policy of prohibiting narcotics abuse. This convention compels every member state to criminalize the perpetrators of narcotics abuse. At the United Nations session in New York, March 30, 1961, the Single Convention on Narcotics Drugs 1961 was issued which produced a list of narcotics included in international control (schedule 1961). Each member country must report the use of narcotic substances periodically to the International Narcotics Control Board (INCB). ${ }^{10}$

In Indonesia, regulations regarding narcotics are regulated in Act No. 35 of 2009 concerning Narcotics. The law was formed on the basis of Article 5 paragraph 1 and Article 20 of the 1945 Constitution of the Republic of Indonesia (UUD 1945), Act No. 8 of 1976 concerning the Ratification of the Single Convention on Narcotics 1961 and its 1972 Protocol which amended it (State Gazette of the Republic of

\footnotetext{
${ }^{8}$ Redaksi Ensiklopedia Indonesia, 1992, Ensiklopedia Indonesia Edisi Khusus, ed. 6, Intermasa, Jakarta, p. 2336.

${ }^{9}$ Exemplification of the Act No. 36 of 2009 concerning Health, Article 102 Paragraph 1.

${ }^{10}$ Anang Iskandar, 2019, Penegakan Hukum Narkotika (Rehabilitatif Terhadap Penyalahguna dan Pecandu, Represif Terhadap Pengedar), Elex Media Komputindo, Jakarta, p. 3-4.
} 
Indonesia of 1976). Number 36, Supplement to the State Gazette of the Republic of Indonesia Number 3085), and Act No. 7 of 1997 concerning Ratification of the United Nations Convention Against Illicit Traffic in Narcotics Drugs and Psychotropic Substances, 1988 (United Nations (UN) Convention concerning the eradication of illicit trafficking in narcotics and psychotropic substances. , 1988) (State Gazette of the Republic of Indonesia of 1997 Number 17, Supplement to the State Gazette of the Republic of Indonesia Number 3673).

Article 5 chapter III of Act No. 35 of 2009 concerning Narcotics concerning the scope states that the regulation of narcotics in this law includes all forms of activities and/or actions related to narcotics and narcotic precursors. Narcotics precursors are substances or starting materials or chemicals that can be used in the manufacture of narcotics which are distinguished in the table as attached in Act No. 35 of 2009. As in the Law, narcotics are classified into: narcotics class I, narcotics class II, and narcotics class III. These three groups are contained in the annexes to Act No. 35 of 2009 concerning Narcotics.

According to Jimiy Asshidiqie, the law enforcement process is an effort to enforce or actually function legal norms as behavioral guidelines in traffic or legal relationships in social and state life. ${ }^{11}$ In relation to law enforcement of narcotics crimes, victims of narcotics crimes are called narcotics users, while the perpetrators of narcotics crimes are narcotics dealers and producers. The Narcotics Law, which is part of law enforcement efforts in Indonesia, regulates "narcotics users" in article 116, article 121, article 126, article 127, article 128, article 134, and other matters in the psychotropic law relating to its users are regulated in article 36 , article 37 , article 38 , article, 39 , article 40 , article 41 , article 59 paragraph 1 letters a and $b$, and article 62 .

Based on article 153 chapter XVII of Act No. 35 of 2009 concerning Narcotics points a and b states,

"With the entry into force of this law:

- Act No. 22 of 1997 concerning Narcotics (State Gazette of the Republic of Indonesia 1997 Number 67, Supplement to the State Gazette of the Republic of Indonesia Number 3698); and

- Attachments regarding the types of psychotropics Group I and Group II as contained in the attachment of Act No. 5 of 1997 concerning Psychotropics (State Gazette of the Republic of Indonesia of 1997 Number 10, Supplement to the State Gazette of the Republic of Indonesia Number 3671) which have been transferred to narcotics class I according to this Law, revoked and declared invalid. ${ }^{12}$

Thus at this time, Act No. 35 of 2009 is used to prevent and eradicate abuse and illicit trafficking of narcotics and narcotics precursors whose mode of operation is increasingly sophisticated, this law also regulates the expansion of wiretapping investigation techniques, covert purchasing techniques (under cover buy), and controlled delivery techniques, as well as other investigative techniques to track and uncover abuse and illicit trafficking of narcotics and narcotic precursors. This law also establishes a non-ministerial government agency (LPNK),

${ }^{11}$ Mirza Dwi Bagustiantara, Ira Alia Maerani, Op. Cit, Results and Discussion.

${ }^{12}$ Act No. 35 of 2009, Op. Cit, Article 153. 
namely the National Narcotics Agency (BNN), which is strengthened by its authority to conduct investigations and investigations. BNN is located under the President and is responsible to the President. Besides that,

In addition, according to the Narcotics Law in force in Indonesia, which regulates efforts to eradicate narcotics crimes through the threat of fines, imprisonment, life imprisonment, and the death penalty. In addition, the law also regulates the use of narcotics for medical and health purposes and regulates medical and social rehabilitation. However, in reality narcotics crime in society is increasing, both quantitatively and qualitatively with widespread victims, especially among children who are still underage, teenagers, and the younger generation. As for criminal threats, it is regulated in Act No. 35 of 2009 concerning Narcotics chapter XV concerning criminal provisions, from article 111 to article 148.

Law enforcement efforts against narcotics crimes are not only the duties and responsibilities of government officials, both those under the ministry or nonministry, but are the responsibility of all of us as citizens of the community. The Narcotics Law also regulates the role of the general public in combating criminal acts of narcotics abuse, as contained in Act No. 35 of 2009 concerning narcotics chapter XIII concerning Community Participation articles 104 to 108. In article 104 which states clearly that "the public has the opportunity to as broadly as possible to participate in assisting the prevention and eradication of abuse and illicit trafficking of narcotics and narcotics precursors". ${ }^{13}$ Despite the various threats of criminal sanctions contained in the Act, it still has not fully provided a deterrent effect for drug offenders.

\subsection{Effectiveness and Phenomenon of Implementing Death Penalty Sanctions in Law Enforcement Against Narcotics Crime Actors}

Criminal provisions and punishment for criminal acts are regulated in the Criminal Code (KUHP) and the Criminal Procedure Code (KUHAP). In the Criminal Code chapter II concerning criminal article 10, the punishment consists of:

- basic punishment: death penalty, imprisonment, confinement, fine, criminal closure.

- additional penalties: revocation of certain rights, confiscation of certain goods, announcement of judge's decision. ${ }^{14}$

Related to narcotics crimes, which was previously discussed in the previous subchapter that law enforcement efforts against narcotics crimes are regulated in Act No. 35 of 2009 concerning narcotics, it also explains criminal sanctions against narcotics abuse, from imprisonment to imprisonment., fines, up to the death penalty.

The death penalty in Indonesia has been going on for a long time, since the Indonesian nation was colonized by the Dutch, until now it is still enforced even

\footnotetext{
13 Ibid, Article 104.

${ }^{14}$ Copy of the Criminal Code (KUHP) Book One, Article 10.
} 
though the Netherlands has abolished the death penalty starting in $1987 .{ }^{15} \mathrm{But}$ on the other hand, the death penalty is still opposed by some Indonesian citizens. The pros and cons regarding the application of the death penalty are represented by 2 (two) currents of thought. First, groups that are against the death penalty stated that the death penalty is not efficient in achieving the goal of a deterrent effect because drug cases have actually increased even though many convicts have been sentenced to death. Other considerations include, the death penalty violates human rights, humans are not God who determines a person's life or death, the death penalty does not educate the public because it teaches cruel and vengeful actions, and sentence decisions and mistakes cannot be corrected after the convict dies, especially in cases of death of the Indonesian courts that have not been proven to be clean, independent, and professional. ${ }^{16}$

Death penalty sanctions are also regulated by laws outside the Criminal Code and in addition to Act No. 35 of 2009 concerning Narcotics, among the laws that threaten the death penalty are the Corruption Law, Psychotropic Law, Terrorism Law, Human Rights Courts. Details of actions that get the death penalty in Act No. 35 of 2009 concerning narcotics can be seen in,

- Article 113 paragraph 2: producing, importing, exporting, or distributing narcotics class I in the form of plants weighing more than $1 \mathrm{~kg}$ or 5 tree trunks or in non-plant form weighing more than 5 grams;

- Article 114 paragraph 2: offers for sale, sells, buys, becomes an intermediary in buying and selling, exchanging, delivering, or receiving narcotics class I which in the form of plants weighs more than $1 \mathrm{~kg}$ or exceeds tree trunks or in nonplant forms weighing 5 grams;

- Article 118 paragraph 2: producing, importing, exporting, or distributing narcotics class II weighing more than 5 grams;

- Article 119 paragraph 2: offering for sale, selling, buying, receiving, intermediary in buying and selling, exchanging, or delivering narcotics class II weighing more than 5 grams;

- Article 121 paragraph 2: the use of narcotics against another person or the administration of class II narcotics to be used by others results in the death of another person or permanent disability. ${ }^{17}$

In the perspective of human rights (ham), the imposition of the death penalty on narcotics criminals is still a problem. Some people have problems in terms of legal instruments, both national and international which regulate human

\footnotetext{
15 Agus Purnomo, Hukuman Mati Bagi Tindak Pidana Narkoba di Indonesia: Perspektif Sosiologi Hukum, Vol. 8 No 1 (2016) url: https://media.neliticom/media/publications/54370-ID-hukumanmati-bagi-tindak-pidana-narkoba.pdf.

16 Aghia Khumaesi Suud, Efektifitas Hukuman Pidana Mati Bagi Pelaku Kejahatan Narkotika, https://puslitbang.kejaksaan.go.id/public/ckfinder/userfiles/files/EFEKTIFITAS\%20HUKUMAN\%20P IDANA\%20MATI\%20BAGI\%20PELAKU\%20KEJAHATAN\%20NARKOTIKA.pdf.

${ }^{17}$ Hanafi Amrani, Ayu Widya Wati, Urgensi Penjatuhan Pidana Mati Terhadap Pelaku Tindak Pidana Narkotika dan Relevansinya Dalam Perspektif Hukum dan Hak Asasi Manusia, Dalam Laporan Penelitian Kolaborasi Fak Hukum UII Yogyakarta (2017) url: https://law.uii.ac.id/wpcontent/uploads/2019/10/Laporan-Penelitian-Agustus-2017.pdf.
} 
rights. Several legal instruments that recognize the existence of human rights, especially the right to life, include the 1945 Constitution, the Human Rights Law, the Universal Declaration of Human Rights, and the International Covenant on Civil and Political Rights (ICCPR). ${ }^{18}$

In electronic media www.news.detik.comwhich was published on Thursday, February 20, 2020 with the title "Indonesia Narcotics Emergency, Drug Dealers Are Rightly Sentenced to Death", Criminal law observer from the University of Riau (UNRI), Dr. Erdianto Effendi stressed that the death penalty is very appropriate for drug dealers, because it has more effect on people who intend to participate in the illicit narcotics business. This was revealed in relation to drug cases that are still rife in Riau, such as at that time an unscrupulous member of the Bengkalis Police was caught red-handed with evidence of $10 \mathrm{~kg}$ of crystal methamphetamine and 60 thousand ecstasy, who were involved in an international drug syndicate. According to Erdianto, narcotics crimes damage the nation's children and stimulate many people to get it the easy way. In addition, the network of illicit goods circulation practices is very difficult to hack by simply sending them to prison, so extraordinary actions must be taken. Moreover, if it involves the legal apparatus, he said, who should enforce the law and be an example of obedience and obedience to the law, it is like the saying "sticks make you fall".19

The resolution of narcotics cases by repressive means is not the only effective solution, this is evidenced by the increasing prevalence of narcotics cases which increased in the 4 th week of December 2018, there were 384 cases. While in January 2019 there were 469 cases, an increase of $22.14 \%{ }^{20}$ During the period from 2017 to early 2019 there were an additional 98 convicts in narcotics cases who were sentenced to death by the court. This number continues to grow along with many other drug cases that are still in legal process. ${ }^{21}$ During the leadership of President Joko Widodo-Jusuf Kalla last year, executions of people convicted of drug cases increased sharply. In the five years since they became supreme leaders, 18 people have died in front of firing squad. According to human rights defender Imparsial, under the pretext of Indonesia's 'narcotics emergency', President Jokowi executed the convicts in three batches. According to Hussein Ahmad, Imparsial researcher, 18 people were convicted of drug cases. Phase I, the execution was carried out on January 18, 2015 with 6 convicts from various countries. On 29 April 2015, 8 people were executed in batch II. ${ }^{22}$

\footnotetext{
18 Ibid.

19 Tim Detikcom, 20 Februari 2020, "Indonesia Darurat Narkotika, Bandar Narkoba Tepat Dihukum Mati”, https://news.detik.com/berita/d-4907395/indonesia-darurat-narkotika-bandar-narkobatepat-dihukum-mati, Retrieved 29 June 2021.

20 Kompas.com, 5 January 2019, "Minggu Pertama Januari, Polisi Sebut Kasus Narkotika Meningkat 22\%", https://nasional.kompas.com/read/2019/01/05/11255661/minggu-pertama-januari-polisisebut-kasus-narkotika-meningkat-22-persenRetrieved 29 June 2021.

21 Rommy Roosyana, August 2, 2019, "Terpidana Mati Dalam Penantian Yang Tak Pasti", https://beritagar.id/artikel/berita/terpidana-mati-dalam-penantian-yang-tak-pasti

22 Muhammad Nur Rochmi, 10 October 2019, "Eksekusi Hukuman Mati di Era Jokowi-JK Naik Tajam", https://beritagar.id/artikel/berita/eksekusi-hukuman-mati-di-era-jokowi-jk-naik-tajam,, Retrieved 29 June 2021.
} 
Narcotics crime is a serious and extra-ordinary crime so that state action must also be firm and strict against narcotics crime. The implementation of the death penalty is not only for a deterrent effect or for the provision of appropriate punishment, but more importantly it is intended to protect the community (defense society) and save the nation's children from the dangers of drug abuse. The statement was conveyed by the Deputy for Law and Cooperation of the National Narcotics Agency (BNN) Ambassador Bali Moniaga, responding to various polemics in the community regarding the implementation of the death penalty in Indonesia. ${ }^{23}$ The implementation of the death penalty does not contradict the 1945 Constitution and the International Covenant on Civil and Political Rights (ICCPR) which has been ratified by Indonesia in article 6 paragraph 1 stating "every human being has the inherent right to life. This right shall be protected by law. No one shall be arbitrarily deprived of his life". However, the ICCPR still allows the death penalty for narcotics crimes, because according to Bali Moniaga as the ambassador for the prevention and eradication of narcotics BNN, narcotics crime is the most serious extra-ordinary transnational organized crime. ${ }^{24}$

Bali Moniaga also emphasized that although the implementation of the death penalty in Indonesia is maintained, its implementation is very selective and tends to be careful. Since the death penalty was imposed in Indonesia, there have been 134 death row inmates, but until now only 22 death row inmates have been executed, so there are 112 more waiting to be executed. When compared to other countries such as America or Malaysia, we are the most selective and very careful in applying the death penalty. Meanwhile, Head of BNN Komjen Pol. Anang Iskandar, stressed the need to immediately implement the death penalty against death row convicts in drug cases which have permanent legal force and there is no further legal action. The death penalty is needed primarily if the person in question while in prison is still distributing narcotics, besides that it is also part of fulfilling the community's sense of justice, and shows the seriousness of the government in law enforcement. It is hoped that the death penalty can be effective in eradicating drug abuse and illicit trafficking in Indonesia. 25

As has been sentenced to death by the court, it turns out that there are still many death row inmates who have not yet been executed. The occurrence of legal uncertainty in carrying out the execution of the death penalty, in turn will lead to public distrust of the law. ${ }^{26}$ In addition, if the victim is indeed a victim of narcotics abuse and does have to undergo rehabilitation, then the article on rehabilitation will also apply. After all, drugs are dangerous things that can damage, both morally and materially, the nation and state.

\footnotetext{
23 Humas BNN, 26 March 2013, "Hukuman Mati Bagi Bandar Narkoba Melindungi dan Menyelamatkan Bangsa Indonesia Dari Bahaya Penyalahgunaan Narkoba", https://bnn.go.id/hukuman-mati-bagi-bandar-narkoba-melindungi-dan-menyelamatkan-bangsaindonesia-dari-bahaya-penyalahgunaan-narkoba/, Retrieved 29 June 2021.

24 Ibid.

25 Ibid.

26 Kelik Wardiono, et al, 2020, Eksekusi Pidana Mati Tindak Pidana Narkotika, Muhammadiyah University Press, Surakarta, p. 5.
} 


\section{Closing}

Theoretically the applicable narcotics law has been very effective in investigating narcotics criminals, and in practice the law is also very helpful in completing investigations against narcotics criminals in Indonesia and the execution of the death penalty is one of the efforts strict law enforcement to emphasize that narcotics abuse is a very dangerous thing. However, the problem of narcotics abuse is not only a national problem, it has become an international problem that cannot be solved only with existing regulations, professionals from law enforcement officials are also very much needed in cracking down on narcotics abuse, and the role of public awareness is also important, in order to stay away from narcotics abuse.

The existence of legal firmness is part of the criminal or civil justice system in Indonesia, but in practice there are still obstacles that undermine the value of the law itself. Regarding narcotics crime which is a very serious crime and must be prevented and eradicated quickly, the death penalty against narcotics crime is very effective. As conveyed by the Deputy for Law and Cooperation of the National Narcotics Agency (BNN) Ambassador Bali Moniaga that the implementation of the death penalty is not only for a deterrent effect or giving appropriate punishment, but more importantly it is intended to protect the community (defense society) and save children of nation from the dangers of drug abuse. So, there is nothing wrong with the articles regarding the death penalty in Act No. 35 of 2009 concerning Narcotics. Even if most of them in practice are still inconsistent and the death penalty must be replaced with life imprisonment, because the Indonesian state still pays attention to the principles of divinity and humanity which must be upheld as a manifestation of Pancasila. In essence, proper punishment should be given to perpetrators of crimes that are commensurate according to the applicable laws and regulations, without violating human rights and not violating other rules, which can lead to bigger conflicts.

\section{References}

\section{Journal}

[1] Aghia Khumaesi Suud, 2020, Efektivitas Hukuman Pidana Mati Bagi Pelaku Kejahatan Narkotika, Jurnal Bina Adhyaksa Puslitbang Kejaksaan Republik $\begin{array}{lllll}\text { Indonesia, } & \text { Vol. } & 10 & \text { No. } & \text { 2, }\end{array}$ https://puslitbang.kejaksaan.go.id/public/ckfinder/userfiles/files/EFEKTIFITA S\%20HUKUMAN\%20PIDANA\%20MATI\%20BAGI\%20PELAKU\%20KEJAHATAN $\% 20 N A R K O T I K A . p d f$.

[2] Agus Purnomo, 2016, Hukuman Mati Bagi Tindak Pidana Narkoba di Indonesia: Perspektif Sosiologi Hukum, Jurnal Hukum dan Syariah Institut Agama Islam Negeri Ponorogo, Vol. 8 No. 1, url: https://media.neliti.com/media/publications/54370-ID-hukuman-mati-bagitindak-pidana-narkoba.pdf.

[3] Hanafi Amrani, Ayu Widya Wati, 2017, Urgensi Penjatuhan Pidana Mati Terhadap Pelaku Tindak Pidana Narkotika dan Relevansinya Dalam Perspektif 
Hukum dan Hak Asasi Manusia, Laporan Penelitian Kolaborasi Fak. Hukum UII Yogyakarta, url: https://law.uii.ac.id/wp-content/uploads/2019/10/LaporanPenelitian-Agustus-2017.pdf.

[4] Mirza Dwi Bagustiantara, Ira Alia Maerani, 2020, Penegakan Hukum Terhadap Pelaku Tindak Pidana Penyalahgunaan Narkotika di Pengadilan Kudus, Jurnal Konferensi Ilmiah Mahasiswa Unissula (KIMU) 4, ISSN. 2720913X,

url: http://jurnal.unissula.ac.id/index.php/kimuh/article/view/12201/4804.

\section{Books}

[1] Anang Iskandar, 2019, Penegakan Hukum Narkotika (Rehabilitatif Terhadap Penyalahgunaan dan Pecandu, Represif Terhadap Pengedar), Elex Media Komputindo, Jakarta.

[2] Irwansyah, 2021, Penelitian Hukum: Pilihan Metode \& Praktik Penulisan Artikel (Edisi Revisi), Cet. 4, Mirra Buana Media, Yogyakarta.

[3] Kelik Wardiono, dkk, 2020, Eksekusi Pidana Mati Tindak Pidana Narkotika, Muhammadiyah University Press, Surakarta.

[4] Rahman Amin, 2020, Perlindungan Hukum Justice Collaborator Dalam Sistem Peradilan Pidana di Indonesia: Studi Perkara Tindak Pidana Narkotika, Deepublish, Yogyakarta.

[5] Redaksi Ensiklopedia Indonesia, 1992, Ensiklopedi Indonesia (Edisi Khusus), Cet. 6, PT. Intermassa, Jakarta.

\section{Regulations}

[1] Constitution of the Republic of Indonesia 1945.

[2] Act No. 35 of 2014 concerning Child Protection.

[3] Regulation of the Head of the National Police of the Republic of Indonesia Number 14 of 2012 concerning Management of Criminal Investigations.

[4] Regulation of the Act No. 35 of 2009 concerning Narcotics.

[5] Regulation of the Act No. 36 of 2009 concerning Health.

[6] Regulation of the Act No. 39 of 1999 concerning Human Rights.

[7] The Criminal Code (KUHP).

[8] The Criminal Procedure Code (KUHAP).

\section{Internet}

[1] Public Relations of BNN, March 26, 2013, url: https://bnn.go.id/tahunanmati-bagi-bandar-narkoba-melindungi-dan-memlamat-bangsa-indonesiadari-Danger-penyalahahan-narkoba/.

[2] Kompas.com, January 5 2019, url: https://national.kompas.com/read/2019/01/05/11255661/minggu-pertamajanuari-polisi-sebut-case-narkotika-meningkat-22-percent.

[3] Makassarmetro, 24 April 2021, url: https://makassarmetro.com/2021/04/24/polisi-tangkap-assisten-i-pemkotmakassar-dugaan-penyalahahan-narkoba. 
[4] Muhammad Nur Rochmi, 10 October 2019, url: https://beritagar.id/article/berita/eksekusi-elektroan-mati-di-era-jokowi-jknaik-tajam.

[5] Rommy Roosyana, 2 August 2019, url: https://beritagar.id/article/berita/terpidana-mati-dalam-penantian-yangtak-pasti.

[6] Sandy Ferdiana, April 7, 2021, url: https://www.republika.co.id/berita/qr6kg8371/kemenkumham-dan-polrirazia-narkotika-di-rutan-perempuan.

[7] Detikcom Team, February 20, url: https://news.detik.com/berita/d4907395/indonesia-darurat-narkotika-bandar-narkoba-tepat-diunjuk-mati.

[8] Vicentius Mario, Andika Aditia, 20 April 2021, url: https://www.kompas.com/hype/read/2021/04/20/092808066/rio-reifan-recaptured-terkait-abuse-narkoba. 